\title{
Species-area relationship and its determinants for mammals in western North American national parks
}

\author{
WILLIAM D. NEWMARK \\ School of Natural Resources, University of Michigan, Ann Arbor, \\ Michigan 48109, U.S.A.
}

Accepled for publication 14 February 1986

\begin{abstract}
The relationship between non-volant mammalian species richness and area in 24 western North American national parks is examined. The exponential and the power function models are concluded to be the 'best' models and account for nearly an identical proportion of the total variance $(\cong 69 \%)$. Two principal hypotheses, the area per se and the habitat diversity hypotheses, have been proposed to explain the species-area relationship. Support exists for both hypotheses based upon partial correlation analysis of non-volant mammalian species richness with area, elevational range, latitude, number of vegetative cover types and index of vegetative cover diversity. I conclude that area per se and habitat diversity defined as environmental heterogeneity are the best predictors of non-volant mammalian species richness in western North American national parks. I also conclude that vegetative cover diversity is a poor predictor of mammalian species richness in western North American national parks. Several problems with assessing the area per se and habitat diversity hypotheses are noted. These are: (1) the definition of the term 'habitat'; (2) the predictions of these two hypotheses may not be mutually exclusive; and (3) area and habitat diversity tend to be intercorrelated. The slope $(z)$ of the power function is equal to 0.12 . The hypothesis that variation in the slope of the power function for nature reserves worldwide is a result of the comparative sizes of the nature reserves cannot be excluded. There has been considerable discussion in recent years about the conservation implications of the species-area relationship. Much of this discussion has been concerned with whether a single large reserve contains more species than several small reserves (SLOSS). The answer to SLOSS is heavily dependent upon the objectives of a reserve, the autecology of the species, and the ecological independence of the reserves. It is suggested that particular attention be given to area and elevation when designing nature reserves.
\end{abstract}

KEY WORDS: - Mammalian species richness - area - elevational range - habitat diversity western North America - national parks - reserve design.

\section{CONTENTS}

Introduction

Mcthods

Results

Species-area relationships .

Correlation among variables

Partial correlation analysis. Discussion .

Area per se and habitat diversity hypotheses

Interpretation of the species-area slope $(z)$.

Implications of the species-arca relacionship for conservation of mammals

Acknowledgements

References. 


\section{INTRODUCTION}

It has been recognized for more than a century that the number of species increases as area increases (De Candolle, 1855; Arrhenius, 1921, 1923; Gleason, 1922, 1925). However, considerable debate still surrounds the biological basis for the species-area relationship (Simberloff, 1978; Connor \& McCoy, 1979; McGuiness, 1984), the interpretation of the slope of the power function (Connor \& McCoy, 1979; Sugihara, 1981), as well as the conservation implications of the species-area relationship (Diamond, 1975; Gilbert, 1980; Simberloff \& Abele, 1976, 1982).

Two principal hypotheses have been proposed to explain the species-area relationship: the habitat diversity hypothesis and the area per se hypothesis (Connor \& McCoy, 1979). Williams (1943) was the first to propose the habitat diversity hypothesis. He suggested that as larger areas are sampled, an increasing number of habitats will be encountered; thus larger areas contain more species because they contain greater habitat diversity. The area per se hypothesis was developed by Preston $(1960,1962)$ and MacArthur \& Wilson $(1963,1967)$, who suggested that the number of species on an island represents an equilibrium between the rates of extinction and colonization. They assumed that the rate of colonization is dependent upon the distance of an island from a source pool and that the rate of extinction is inversely proportional to population size which in turn depends upon the island area.

In order to corroborate the habitat diversity hypothesis, it must be shown that for islands of equal area, a positive relationship exists between habitat diversity and number of species. Conversely, in order to demonstrate the area per se hypothesis, it must be shown that in a homogeneous habitat a positive relationship exists between area and species number (Simberloff, 1978; Connor \& McCoy, 1979). Unfortunately, variation in the size and habitat diversity of western North American national parks does not permit a natural experiment, I will therefore use correlation analysis to identifiy the best predictors of mammalian species richness.

In this paper, I examine the relationship between non-volant mammalian species richness in 24 western North American national parks and area, elevational range, latitude, number of vegetative cover types and index of vegetative cover diversity. I discuss the problems of assessing the area per se and habitat diversity hypotheses. In addition, I examine the relationship between number of non-volant mammals and area within western North American national parks and park assemblages and compare it to species-area relationships in Western Australian, and East African reserves. Finally I discuss the conservation implications of the species-area relationship as they apply to the design of nature reserves for mammals.

\section{METHODS}

Twenty-nine national parks and park assemblages in the western U.S. and Canada were included in this study. For purpose of analysis, parks that were contiguous with another park were considered to be a single park assemblage (Bekele, 1980), because of the freedom of movement for the park fauna between the contiguous parks. Thus a total of 24 national parks and park assemblages was included in the analysis (Table 1). All parks are located in the Rocky 
Table 1. Untransformed data used in analysis

\begin{tabular}{|c|c|c|c|c|c|c|c|}
\hline & $\begin{array}{l}\text { Park-- } \\
\text { park assemblage }\end{array}$ & $\begin{array}{l}\text { Iammalian } \\
\text { species } \\
\text { richness }\end{array}$ & $\begin{array}{c}\text { Area } \\
\left(\mathrm{km}^{2}\right)\end{array}$ & $\begin{array}{l}\text { Latitude } \\
\qquad\left({ }^{\circ} \mathrm{N}\right)\end{array}$ & $\begin{array}{c}\text { Elevational } \\
\text { range } \\
\text { (m) }\end{array}$ & $\begin{array}{l}\text { Number of } \\
\text { vegetative } \\
\text { cover } \\
\text { types }\end{array}$ & $\begin{array}{c}\text { Index of } \\
\text { vegetative } \\
\text { cover } \\
\text { diversity }\end{array}$ \\
\hline 1 & Wind Caves & 33 & 112 & 43.58 & 365 & 4 & 0.31 \\
\hline 2 & Grand Teton-Yellowstone & 55 & 10328 & 44.28 & 2347 & 9 & 0.60 \\
\hline 3 & Glacier- Waterton Lakes & 56 & 4627 & 48.71 & 2213 & 9 & 0.79 \\
\hline 4 & Kootenay-Banff-Jasper-Yoho & 1055 & 20736 & 52.27 & 2887 & 10 & 0.83 \\
\hline 5 & Glacier (Canada) & 39 & 1349 & 51.27 & 2535 & 8 & 0.77 \\
\hline 6 & Mount Revelstoke & 36 & 262 & 51.09 & 2150 & 7 & 0.72 \\
\hline 7 & Manning Provincial & 48 & 712 & 49.11 & 1509 & 6 & 0.54 \\
\hline 8 & Olympic & 46 & 3628 & 47.83 & 2428 & 8 & 0.64 \\
\hline 9 & Mount Rainier & 40 & 976 & 46.86 & 3897 & 8 & 0.38 \\
\hline 10 & Crater Lake & 43 & 641 & 42.77 & 1501 & 6 & 0.67 \\
\hline 11 & Lava Beds & 33 & 185 & 41.77 & 457 & 5 & 0.39 \\
\hline 12 & Lassen Volcanic & 42 & 426 & 40.50 & 1439 & 7 & 0.68 \\
\hline 13 & Yosemite & 57 & 2083 & 37.83 & 3293 & 10 & 0.80 \\
\hline 14 & Sequoia-Kings Canyon & 59 & 3389 & 36.77 & 3991 & 9 & 0.73 \\
\hline 15 & Wupatki & 30 & 143 & 35.56 & 335 & 3 & 0.40 \\
\hline 16 & Grand Canyon & 57 & 4931 & 36.23 & 2275 & 6 & 0.52 \\
\hline 17 & Zion & 49 & 588 & 37.32 & 1463 & 5 & 0.68 \\
\hline 18 & Bryce Canyon & 33 & 144 & 37.51 & 762 & 5 & 0.56 \\
\hline 19 & Capitol Reef & 32 & 979 & 38.08 & 320 & 4 & 0.46 \\
\hline 20 & Arches & 33 & 293 & 38.73 & 488 & 4 & 0.50 \\
\hline 21 & Dinosaur & 42 & 827 & 40.44 & 1262 & 7 & 0.32 \\
\hline 22 & Colorado & 30 & 83 & 39.06 & 670 & 4 & 0.49 \\
\hline 23 & Mesa Verde & 44 & 208 & 37.25 & 713 & 3 & 0.43 \\
\hline 24 & Rocky Mountain & 44 & 1049 & 40.35 & 1809 & 8 & 0.75 \\
\hline
\end{tabular}

Mountains, Sierra-Cascades or Colorado Plateau (Fig l). The legal size or area $(A)$ of the western North American national parks and park assemblages was taken from IUCN (1980).

Non-volant mammalian species richness $(S)$ was determined by reviewing the literature and the park sighting records (Newmark, 1986). Species which have been sighted fewer than three times since park establishment were excluded from the analysis, because these species were considered to be transients. All non-volant mammalian exotics were included in the analysis because of their non-transient nature; i.e. in all cases they are species which have established breeding populations within a park.

Elevational range $(E)$ has been widely recognized as an indirect indicator of environmental diversity (Hamilton \& Armstrong, 1965; Johnson \& Raven, 1973; Power, 1976; Patterson, 1980). Most western North American national parks and park assemblages display a large elevational range. Elevational range for each park was taken from U.S. Geological Survey and Canadian Army Survey and Canadian Department of Energy, Mines, and Resources topographical maps.

The inverse relationship between latitude $(L)$ and number of species has long been recognized (Wallace, 1878; Fischer, 1960; Simpson, 1964). The latitude of the centre of each reserve was taken from the U.S. and Canadian topographical maps.

The number of vegetative cover types $\left(\mathcal{N}_{\mathrm{v}}\right)$ within each park was calculated. Twenty-five vegetative cover types were identified in the 24 parks and park 


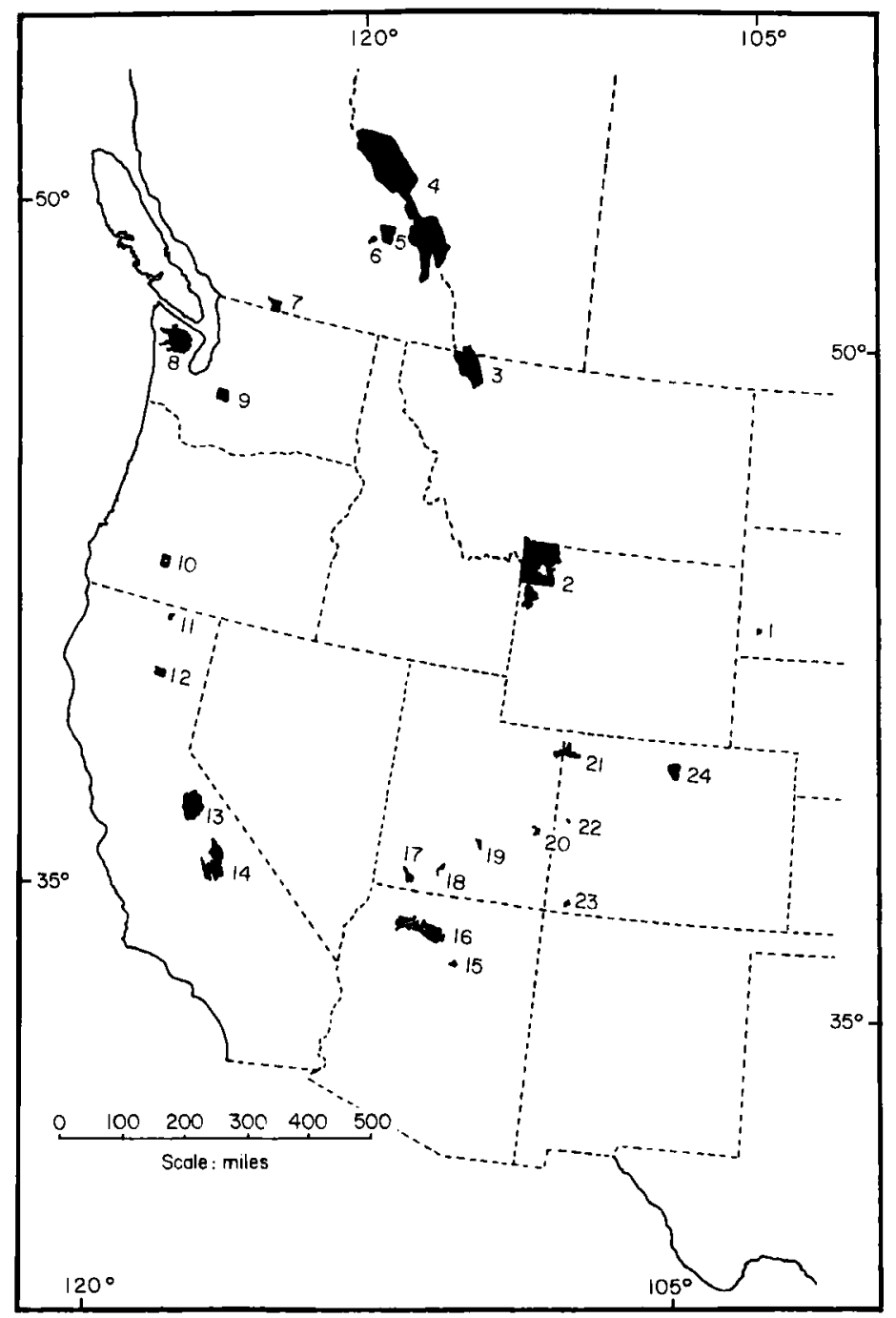

Figure 1. Map of western North American showing location of 24 national parks and park assemblages listed in Table 1.

assemblages from existing National Park Service and Parks Canada vegetative cover type maps (Table 2). The cover types listed in Table 2 are based principally upon the dominant upper story vegetation. The criterion for inclusion was that a given vegetative cover type within a park must cover at least $1 \%$ of the park.

An index of vegetative cover diversity $\left(V_{\mathrm{CD}}\right)$ was developed based upon the Shannon-Wiener diversity index. The index of vegetative cover diversity may be described as:

$$
V_{\mathrm{CD}}=-\sum_{i=1}^{n} p_{i} \log _{\mathrm{e}} p_{i}
$$

where $p_{i}$ is the relative frequency of the $i$ th vegetative cover type listed in Table 2. 
Table 2. Vegetative cover types in 24 western North American national parks and park assemblages used in analysis. Vegetative cover types were identified from National Park Service and Parks Canada vegetative cover type maps

\begin{tabular}{|c|c|c|c|c|c|}
\hline 1 & Alpine & 10 & Douglas fir & 19 & Sagebrush \\
\hline 2 & Engelmann spruce/subalpine fir & 11 & Redwood & 20 & Creosotebrush/saltbrush \\
\hline 3 & Whitebark pine & 12 & Larch & 21 & Blackbrush \\
\hline 4 & Lodgepole pine & 13 & Ponderosa pine/Jeflerey pine & 22 & Scrub \\
\hline 5 & Mountain hemlock & 14 & Oak woodland & 23 & Grassland/meadow \\
\hline 6 & Red fir/white fir & 15 & Aspen & 24 & Riparian \\
\hline 7 & Silver fir & 16 & Pinyon pine/juniper & 25 & Barren \\
\hline 8 & Western hemlock & 17 & Chaparral & & \\
\hline 9 & Sitka spruce & 18 & Shrub/brush & & \\
\hline
\end{tabular}

Statistical calculations were conducted using the Michigan Interactive Data Analysis System. The least-squares method was used for all regression analyses. Species-area regressions were calculated using the linear (species/area), exponential (species/log area), and power function (log species/log area) models (Connor \& McCoy, 1979). The power function model is:

$$
S=C A^{2},
$$

where $S$ is number of species, $A$ is area and $C$ and $z$ are constants. The power function is approximated by the double $\log$ transformation:

$$
\log S=\log C+z \log A \text {. }
$$

The exponential model is:

$$
S=\log C+z \log A
$$

The linear model is:

$$
S=C+z A .
$$

Determination of the 'best fit' was identified by examining alternative models for lack of systematic error (Sugihara, 1981). Specifically, I plotted the residuals against the independent terms and examined them for non-linearity and nonconstancy of error variance (Neter \& Wasserman, 1974). The Lilliefors test (Conover, 1971) was used to test for normality of error terms.

Partial correlation analysis was conducted between non-volant mammalian species richness and area, elevational range, latitude, number of vegetative cover types and index of vegetative cover diversity to identify the isolated effects' of each of these variables (Morrison, 1967). Partial correlation analysis was used instead of stepwise multiple regression analysis because of the problems associated with the order in which the independent variables enter the stepwise regression analysis. That is, for variables that are highly correlated, such as area and indices of habitat diversity, the variable that enters the regression equation first will always explain a larger proportion of the total variation of the dependent variable and thus may give a distorted image as to the relative 'importance' of an independent variable. All variables were $\log _{10}$ transformed to normalize their distributions. 


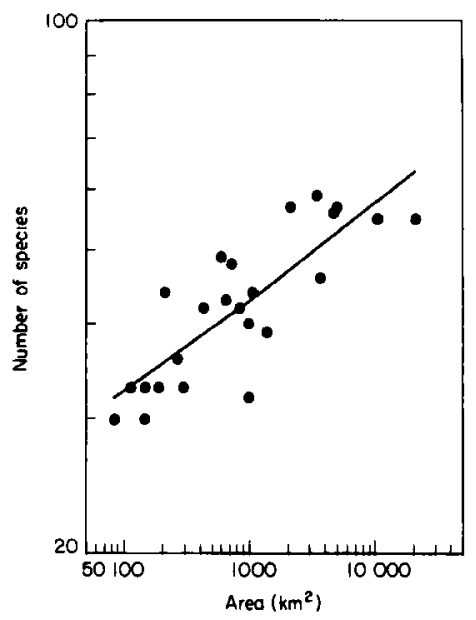

Figure 2. The relationship between $\log _{10}$ number of species of non-volant mammals and $\log _{10}$ area of 24 western North American national parks and park assemblages. $\log S=1.26+0.12(\log A)$, $r^{2}=0.68, P<0.001, \mathcal{N}=24$.

\section{RESULTS}

\section{Species-area relationships}

The exponential and the power function models were considered to be the 'best' models because they did not violate the assumptions of linearity, constancy, or normality of error terms. Species richness was significantly correlated $(P<0.001)$ with area of the western North American national parks and park assemblages for both the exponential and power function models (Fig. 2). These two models accounted for a nearly identical proportion $(\cong 69 \%$ ) of the total variance (Table 3 ).

\section{Correlation among variables}

Mammalian species richness was positively correlated with area, elevational range, number of vegetative cover types and index of vegetative cover diversity for $\log _{10}$ transformed data (Table 4). This indicates that large parks with a greater elevational range, higher vegetative cover diversity and a large number of vegetative cover types support a greater number of species. Latitude was the only variable not significantly correlated with species richness.

Area was significantly correlated with number of vegetative cover types, elevational range and the index of vegetative cover diversity. This indicates that area and possible indicators of habitat diversity are intercorrelated.

Table 3. Results of species-area regression analysis for 24 western North American national parks and park assemblages

\begin{tabular}{lccl}
\hline \multicolumn{1}{c}{ Regression model } & \multicolumn{2}{c}{ test, } & $\mathcal{N}$ \\
\hline Exponential, $S=7.26+12.32(\log A)$ & $r^{2}$ & $P$ & \\
Power function, $\log S=1.26+0.12(\log A)$ & 0.69 & $<0.001$ & 24 \\
\hline
\end{tabular}


Table 4. Correlation matrix of $\log _{10}$ transformed data for 24 western North American national parks and park assemblages

\begin{tabular}{lcccccc}
\hline & $S$ & $A$ & $E$ & $V_{\text {CD }}$ & $\mathcal{N}_{\mathbf{v}}$ & $L$ \\
\hline$(S)$ Mammalian species richness & - & & & & & \\
(I) Area & 0.83 & - & & & & \\
$(E)$ Elevational range & 0.79 & 0.72 & - & & & \\
$\left(V_{\text {CD }}\right.$ Index of vegetative cover diversity & 0.57 & 0.54 & 0.65 & - & & \\
$\left(\mathcal{N}_{\mathrm{V}}\right)$ Number of vegetative cover types & 0.71 & 0.77 & 0.89 & 0.64 & - & \\
$(I$.$) Latitude$ & 0.15 & 0.35 & 0.43 & 0.30 & 0.52 & - \\
\hline
\end{tabular}

$P<0.05, r=0.40 ; P<0.01, r=0.52 ; P<0.001, r=0.63 ; \mathrm{df}=22$.

\section{Partial correlation analysis}

Partial correlation analysis showed that area was significantly correlated with mammalian species richness after holding elevational range, latitude, number of vegetative cover types and the vegetative cover diversity index constant (Table 5). Elevational range was also significantly correlated with species richness after holding area, latitude, number of vegetative cover types and index of vegetative cover diversity constant. Neither latitude, the number of vegetative cover types, nor the index of vegetative cover diversity index were significantly correlated with species richness when the other variables were held constant. These results indicate that both area per se and elevational range are significantly correlated with mammalian species richness in western North American national parks when the effects of latitude, vegetative cover and vegetative cover diversity are partialled out, but that latitude, vegetative cover and vegetative cover diversity are not significantly correlated with species richness when the effects of area and elevation are partialled out.

\section{DISCUSSION}

\section{Area per se and habitat diversity hypotheses}

Partial correlation analysis indicates that area per se is an important predictor of mammalian species richness in western North American national parks. This is consistent with the hypothesis that larger areas normally contain larger populations which in turn have lower probabilities of extinction (MacArthur \&

Table 5. Partial correlations between non-volant mammalian species richness and area, elevational range, latitude, index of vegetative cover type diversity and number of vegetative cover types. The partial correlation of each variable with species richness was calculated by holding all other variables constant

\begin{tabular}{lcc}
\hline \multicolumn{1}{c}{ Variable } & $r_{\text {partial }}$ & t test, $P$ \\
\hline Area & 0.67 & $<0.01$ \\
Elevational range & 0.54 & $<0.025$ \\
Latitude & -0.40 & n.s. \\
Number of vegetative cover types & -0.20 & n.s. \\
Index of vegetative cover diversity & 0.10 & n.s. \\
\hline
\end{tabular}


Wilson, 1967; Diamond, 1984a). Additional support for this hypothesis within western North American national parks is twofold.

First, within 14 of the 24 western North American national parks and park assemblages included in this study, a significant inverse relationship exists between number of natural post-establishment extinctions of lagomorphs, carnivores and artiodactyls and park area $(r=0.72 ; P<0.01)$. Analysis was limited to 14 parks and the orders Lagomorpha, Carnivora and Artiodactyla, because these parks and orders had the most complete historical and current species sighting records. The regression equation describing this relationship is $y=11.82-2.68 \log$ area (Newmark, 1986). Results will be reported more fully in the future.

Second, for populations of lagomorphs, carnivores and artiodactyls that have gone extinct since park establishment in western North American national parks and park assemblages, estimated initial population size is the most consistent predictor of the log of the ratio of the odds of persistence/extinction. This result is based upon regressing persistence/extinction of populations of lagomorphs, carnivores and artiodactyls on park age, initial population size, body weight, index of ecological specialization, age of maturity and successional stage affinity using multiple logistic regression analysis (Newmark, 1986). These results also will be reported more fully in the future.

Partial correlation annysis also indicates that elevational range is an important predictor of mammalian richness in western North American national parks. This result is consistent with findings by Patterson (1984) who reported a significant relationship between number of montane mammals and elevation in the southern Rocky Mountains.

It has been recognized since before the turn of the century that many mammals in western North America are distributed along elevational gradients (Merriam, 1890; Grinnell \& Storer, 1924; Hall, 1946). In addition, Simpson (1964) has shown that for North America, the mountainous regions are the centres of highest mammalian species diversity.

Elevational range is an important predictor of mammalian species richness in western North American national parks, because an increase in elevational range is most likely associated with an increase in environmental heterogeneity. It is well known that elevation is correlated with temperature, precipitation, humidity, wind speed, evaporation and insolation in western North America (Whittaker, 1960; Marr, 1967). Thus greater elevational range should reflect greater climatic and substrate diversity. It is most likely that this increase in climatic and substrate diversity is responsible for the observed increase in mammalian species richness. An increase in climatic and substrate diversity should increase the opportunity for the ecological segregation of species as a result of behavioural and physiological differences between species (Terborgh, 1971; Brown, 1971; Heller \& Gates, 1971; Diamond, 1973). Heller (1971) and Heller \& Gates (1971) have demonstrated for four species of chipmunks (Eutamias spp.) in the Sierra Nevadas in California, that individual physiological tolerances of the species as well as their relative competitive abilities are important determinants affecting their elevational distribution. These results are further supported by Brown (1971) who has shown that two species of chipmunks (Eutamias umbrinus and E. dorsalis) in the Great Basin are segregated along elevational gradients as a result of interspecific competition. 
Partial correlation analysis indicates that habitat diversity, defined as either the number of vegetative cover types or as an index of vegetative cover diversity, is a poor predictor of mammalian species richness in western North American national parks. I propose several explanations for the insignificant correlations between mammalian species richness and vegetative cover diversity in western North American national parks.

First, it is possible that the dominant upper-story vegetation, upon which the two vegetative cover diversity indices are based, is less important in defining the habitat requirements for mammals than the middle and ground-level vegetation. However, many of the vegetative cover types that were used in the analysis are single strata. While little work has been conducted on the importance of vegetative strata on mammalian richness, there has been considerable work done on the importance of vertical height diversity on avian richness (e.g. MacArthur \& MacArthur, 1961; Karr, 1968; Rotenberry \& Wiens, 1980). Lynch \& Whigham (1984) have shown that individual bird species in the eastern deciduous forests of the U.S. respond differentially to specific structural and floristic characteristics of the forest. It is possible that mammals respond similarly.

A second possible explanation for the insignificant correlation between number of mammalian species and vegetative cover diversity is that vegetative cover diversity may not be important in defining habitat diversity with regard to mammalian richness. While this explanation runs counter to the widely accepted definition of habitat as being the vegetative cover of an environment (Ricklefs, 1979; Karr, 1980), it is consistent with the findings of several other workers (Brown, 1978; Lawlor, 1983). Brown (1978) reported an insignificant correlation between number of montane mammals on mountaintops in the Great Basin and an index of habitat diversity, developed by Johnson (1975), based upon the number of coniferous tree species and three mesic vegetative cover types. Additionally, Lawlor (1983) reported an insignificant correlation between number of mammals and number of plant species on landbridge islands in the Sea of Cortéz off Mexico.

To my knowledge, only two studies have concluded that habitat diversity, as estimated by vegetative cover diversity, is the principal predictor of mammalian richness in western North America when both area and habitat diversity area included in the analysis; however, both of these studies are inconclusive. Lawlor (1983) reported that distance to the mainland and number of plant species were the best predictors of number of mammals on oceanic islands in the Sea of Cortéz and concluded that isolation and environmental complexity as estimated by number of plant species are the principal determinants of mammalian richness on these islands. However, it is possible that the number of plant species is intercorrelated with some third variable, such as annual precipitation, which is affecting both numbers of species of mammals and plants either directly or indirectly. Abramsky \& Rosenzweig (1984) have shown that annual precipitation, which they suggest reflects productivity, is a good predictor of number of rodent species in rocky and sandy habitats in Israel and in sandy habitats in the deserts of southwestern U.S. Secondly, Bekele (1980) reported the number of potential natural vegetation types (Küchler, 1966) to be the best predictor of number of large mammals in 14 western U.S. national parks. 
The obvious contradiction between results presented here and those of Bekele (1980) deserves further comment. First, it is questionable whether the number of potential natural vegetation types (Küchler, 1966) should reflect 'more truly' habitat diversity than an index based upon existing vegetative cover types. Secondly, using a more recent edition of the vegetation map (Küchler, 1975), I calculated a different number of potential natural vegetation types for many of the same 14 western U.S. national parks that Bekele (1980) included in his analysis. Using these more recent data, I found an insignificant partial correlation $(P>0.1)$ between number of species of mammals and number of potential natural vegetation types in 20 western U.S. national parks when area, elevational range and latitude were held constant (20 instead of 24 western North American parks and park assemblages were included in the analysis because Küchler's potential natural vegetation classification system is limited to the contiguous U.S.). Further detailed studies of the relationship between vegetative diversity and mammalian richness are needed.

A third possible explanation for the insignificant correlation between species richness and vegetative cover diversity is that vegetative cover diversity may be more important for local or alpha diversity than for regional or beta diversity (MacArthur, 1965; Ricklefs, 1979). Given the large geographic expanse of the 24 national parks and park assemblages included in this study, it is quite possible that vegetative cover diversity is not reflective of regional or beta diversity. Elevational range is possibly a better measurement of regional or beta diversity.

It is apparent that several factors complicate the assessment of the relative importance of area per se and habitat diversity in explaining species-area relationships in western North American national parks. First is the inadequacy of existing definitions of the term 'habitat' to explain mammalian species richness in western North American national parks. The definition of the term 'habitat' as the vegetative cover of an environment (Ricklefs, 1979; Karr, 1980) is unsatisfactory because of the poor correlation of numbers of non-volant mammals with vegetative cover diversity in western North American national parks. In addition, the definition of habitat as a $m$-dimensional space in which a species exists (Whittaker, Levin \& Root, 1973) is unsatisfactory because it is too broad to be of any predictive value.

A second factor which makes it difficult to assess the relative importance of area per se and habitat diversity in western North American national parks is that the predictions of the area per se and habitat diversity hypotheses may not be mutually exclusive (Simberloff, 1978; Connor \& McCoy, 1979; Gilbert, 1980). Support for both hypotheses exists. Simberloff (1976) and Rey (1984) have confirmed experimentally the importance of area per se as a predictor of number of arboreal arthropods on small mangrove and Spartina islands off the coast of Florida. Harman (1972) and Abele (1974) have provided support for the importance of habitat diversity in predicting number of species of aquatic invertebrates in marine and fresh water environments, and MacArthur \& MacArthur (1961) have demonstrated the importance of habitat diversity in predicting avian species richness in eastern North America. It is quite possible that in one region or for one taxon, area may be an important predictor of number of species while in another region or for another taxon, habitat diversity may be an important predictor. Finally, it is possible that both area per se and 
habitat diversity may be important predictors in the same region or for the same taxon as it appears to be with non-volant mammals in western North American national parks.

A third factor which complicates the assessment of the relative importance of area per se and habitat diversity is that area and indices of habitat diversity tend to be intercorrelated (e.g. Power, 1972, 1976; Brown, 1978; Kitchener et al., 1980; Reed, 1983; Lynch \& Whigham, 1984). An examination of the correlation matrix (Table 4) indicates that within western North American national parks, area and possible indicators of habitat diversity (elevational range, number of vegetative cover types, and index of vegetative cover diversity) are positively correlated.

Partial correlation analysis shows that both area per se and elevational range are important predictors of mammalian species richness in western North American national parks. Area per se is probably important because larger areas contain larger populations which in turn have a higher probability of persistence. Elevational range is important because an increase in elevational range is most likely associated with an increase in environmental heterogeneity which in turn allows for greater ecological segregation of species. Finally, vegetative cover diversity is a poor predictor of mammalian richness in western North American national parks.

\section{Interpretation of the species-area slope ( $\mathrm{z}$ )}

Although western North American national parks are becoming increasingly isolated as a result of disturbance on lands adjacent to the parks, they are not yet true habitat islands. The slope of the power function for the species-area relationship $(z=0.12)$ indicates that western North American national parks and park assemblages are more similar to non-isolated continental samples than to true isolates. MacArthur \& Wilson (1967) and Lawlor (1986) report that the slope for most non-isolated continental samples is between 0.12 and 0.17 and the slope for true isolates is between 0.20 and 0.35 .

The slope of the power function for the species-area relationship for western North American national parks differs from the reported slopes for other groups of nature reserves worldwide. Kitchener et al. (1980) report a slope of 0.39 for non-volant mammals in nature reserves in Western Australia. Miller \& Harris (1977) did not find a significant species-area relationship for large mammals in East African national parks. However, Western \& Ssemakula (1981), when comparing East African parks by habitat type, found a significant species-area relationship with a slope $(z)$ of $0.04-0.08$. The variation in the slope of the species-area regression of nature reserves worldwide may be related to the relative isolation of the parks, the relative transience of the species or the comparative sizes of the reserves. Unfortunately, quantitative data are unavailable to examine the first two hypotheses; however, from general qualitative descriptions in the literature of Western Australian and East African reserves, it appears that Western Australian reserves are much more isolated than either western North American or East African reserves.

Martin (1981) has shown that the slope of the power function will vary according to the size of the islands forming an archipelago. Archipelagos with small islands tend to have steeper slopes than archipelagos with large islands. 
Martin (1981) suggested that this empirical relationship is a result of the asymptotic nature of the species-area relationship. This hypotheses cannot be rejected based upon the comparative slopes and sizes of the Western Australian, western North American and East African parks. Western Australian parks are the smallest group of parks $\left(\overline{\mathbf{x}}=10 \mathrm{~km}^{2}\right)$ and have the steepest slope $(z=0.39)$, followed by western North American parks which are intermediate in size $\left(\overline{\mathbf{x}}=2446 \mathrm{~km}^{2}\right)$ and slope $(z=0.12)$, followed by the East African parks which are the largest parks $\left(\overline{\mathbf{x}}=5643 \mathrm{~km}^{2}\right)$ and have the shallowest slope $(z=0.04-0.08)$.

\section{Implications of the species-area relationship for conservation of mammals}

There has been considerable discussion in recent years as to the conservation implications of the species-area relationship. Much of this discussion has been concerned with the utility of the species-area relationship in developing guidelines for reserve design (Diamond, 1972, 1975; Simberloff \& Abele, 1976, 1982; Gilbert, 1980; Reed, 1983). A general consensus now exists that a single large reserve will contain initially more species and lose fewer species over time than a single small reserve. This relationship holds as long as the species-area curve does not flatten out. The positive relationship between non-volant mammalian species richness and area for western North American national parks as well as the inverse relationship between number of post-establishment extinctions of lagomorphs, carnivores and artiodactyls and park area provides further support for this relationship (Newmark, 1986).

A more contentious question has been whether a single large reserve will contain more species than several small reserves of equivalent size, referred to by the acronym SLOSS (e.g Simberloff \& Abele, 1976, 1982; Wilcox \& Murphy, 1985). In large part the answer to SLOSS depends upon the reserve objectives, the ecological independence of the reserves (Shaffer \& Samson, 1985), as well as the autecology of the species being protected.

If the primary objective of a nature reserve is to maximize species richness, then the answer to SLOSS is largely contingent upon the slope of the regression curve and the similarity of species composition between reserves (Simberloff \& Abele, 1976). It is now generally agreed that two small reserves in different habitats will normally contain more total species than a single large reserve (Higgs \& Usher, 1980; Gilpin \& Diamond, 1980; Simberloff \& Abele, 1982; Soulé \& Simberloff, 1986).

If on the other hand the primary objective of a nature reserve is to minimize species extinctions, then the answer to SLOSS is strongly dependent upon the autecology of the species being protected as well as the ecological independence of the reserves to stochastic extinction events (Shaffer \& Samson, 1985). As has been frequently stated, species are not equal (e.g. Diamond, 1976). Humphrey \& Kitchener (1982) have shown that in Western Australian nature reserves, a single reserve contains more vertebrate species that cannot use habitat adjacent to the reserve than two small reserves of equivalent size, while two small reserves contain more total vertebrate species that can use habitat adjacent to the reserves than a single large reserve. These results are similar to those of Blake \& Karr (1984) who have reported that a single large forest in Illinois contains more long-distance avian migrants than two small forests of equivalent size, but 
that two small forests contain more short-distance avian migrants, residents and total species than a single large reserve.

The importance of recognizing the autecology of the species being protected when designing nature reserves is further dramatized by the results of Patterson \& Atmar (1986) who have shown that the loss of species of montane mammals in the southern Rocky Mountains follows a nested subset pattern. They explain this phenomena as a result of smaller areas containing smaller populations which have higher probabilities of extinction. Support for this hypothesis is provided by the significant inverse relationship between the log of the ratio of the odds of persistence/extinction and estimated initial population size of lagomorphs and carnivores in western North American national parks (Newmark, 1986). This implies that there is a critical area requirement for most montane mammals in western North America. Nature reserves can be expected in the long run to support only those species that have an area requirement smaller than the reserve.

The issue of minimum critical size for nature reserves is particularly important for mammals because as a group, mammals are comparatively poor colonizers (Newmark, 1986; Lawlor, 1983, 1986; Heaney, 1986; Morgan \& Woods, 1986). Heaney (1986) estimates that the rate of colonization for mammals in the Philippines across saltwater barriers less than $15 \mathrm{~km}$ is approximately one successful colonization per $250000-500000$ years. Morgan \& Woods (1986) estimate the rate of colonization for non-volant mammals into the West Indies across saltwater barriers as one colonization for every 1.5-3.1 million years. The poor colonizing ability of mammals is further reflected in the low relative turnover of mammals (Crowell, 1986) in comparison with other invertebrate and vertebrate taxa (Schoener, 1983) on oceanic islands.

While most nature reserves are not surrounded on all sides by saltwater barriers, it is quite likely in the future that the habitat adjacent to most nature reserves will become increasingly inhospitable to mammalian dispersal. Approximately $85 \%$ of the lands adjoining the western North American national parks are public lands (Newmark, 1986). Yet within 14 of the 24 western North American national parks included in this study with the best historical current species sighting records (park age, $\bar{x}=75.1$ years), there have been only three post-establishment natural colonizations by species of lagomorphs, carnivores and artiodactyls not previously found within the parks (Newmark, 1986). This is equivalent to a rate of one colonization per 350 years.

Corridors between nature reserves should enhance the potential for colonization by non-volant mammals (Diamond, 1975; Harris, 1984). Yet the benefits of promoting colonization must be weighed against the risks of introducing disease and exotic species. The impacts of disease and introduced species upon isolated populations can be severe and have been identified as two of the most important factors responsible for the historical extinction of most isolated vertebrate species (Diamond, 1984b; Frankel \& Soulé, 1981). Thus, given the poor colonizing ability of most mammals and the problems associated with corridors, it is critical that particular emphasis be placed upon maximizing reserve area when designing nature reserves for mammals.

It is widely recognized that reserve area and elevation are normally only two of several criteria that are considered when designing a reserve. Issues such as acquisition and maintenance costs, introduction of exotic species, poaching and 
promotion of rural development are also frequently of equal concern when planning nature reserves (McNeeley \& Miller, 1984). Nonetheless, there are several additional practical reasons why special attention should be given to variables such as reserve area and elevation. First, area and elevation are relatively easy to measure in comparison to habitat diversity and can be taken readily from topographic maps. Secondly, area and to a lesser degree elevation have been shown to be consistently correlated with species richness for a wide variety of taxa. In contrast, most indices of habitat diversity tend to be taxonspecific. That is, most indices of habitat diversity which have proven to be successful in predicting species richness for one taxon are generally poor in predicting species richness for another taxon (e.g. Brown, 1978). Thus, given the limited resources facing most conservation organizations, it would be prudent if particular attention be given to such easily measured variables as area and elevation in the selection and design of nature reserves.

\section{ACKNOWLEDGEMENTS}

I would like to thank G. E. Belovsky, K. R. Miller, M. E. Soulé, B. S. Low and B.J. Rathcke for their valuable assistance throughout this study. I also would like to thank L. R. Heaney and B. D. Patterson for their comments on this manuscript. Special thanks are given to M. Kinnaird for drawing Figure 1. Finally, I would like to acknowledge the outstanding assistance I received from the many scientists and resource managers of the National Park Service and Parks Canada who so generously provided information and reviewed species checklists. Support was provided by two Rackham dissertation enhancement grants.

\section{REFERENCES}

ABELE, L. G., 1974. Species diversity of decapod crustaceans in marine habitats. Ecology, 55: 156-161.

ABRAMSKY, Z. \& ROSENZWEIG, M. L., 1984. Tilman's predicted productivity-diversity relationship shown by desert rodents. Nature, 309: 150-151.

ARRHENIUS, O., 1921. Species and area. Journal of Ecology, 9: 95-99.

ARRHENIUS, O., 1923. On the relation between species and area-a reply. Ecology, 4: 90-91.

BEKELE, E., 1980. Island biogeography and guidelines for the selection of conservation units for large mammals. Unpublished Ph.D. dissertation, University of Michigan, Ann Arbor, Michigan.

BLAKE, J. G. \& KARR, J. R., 1984. Species composition of bird communities and the conservation benefit of large versus small forests. Biological Conservation, 30: 173-187.

BROWN, J. H., 1971. Mechanisms of competitive exclusion between two species of chipmunks. Ecology, 52: 305-311.

BROWN, J. H., 1978. The theory of insular biogeography and the distribution of boreal birds and mammals. Great Basin Naturalist Memoirs, 2: 209-227.

DE CANDOLLE, A., 1855. Gégraphie botanique raisonnée: ou, exposition des faites principaux el des lois cancervant la distribution géographique des plantes de l'epoque actuelle. Paris: V. Maisson.

CONNOR, E. F. \& McCOY, E. D., 1979. The statistics and biology of the species-area relationship. American Naturalist, 133: 791-833.

CONOVER, W. J., 1971. Practical Nonparametric Statistics. New York: John Wiley and Sons Inc.

CROWELL, K. L., 1986. A comparison of relict versus equilibrium models for insular mammals of the Gulf of Maine. Biological Journal of the Linnean Society, 28: 37-64.

DIAMOND, J. M., 1972. Biogeographic kinetics: estimation of relaxation times for avifaunas of southwest Pacific islands. Proceedings of the National Academy of Sciences of the U.S.A., 69: 3199-3203.

DIAMOND, J. M., 1973. Ecological consequences of island colonization by southwest Pacific birds, I. Types of niche shifts. Proceedings of the National Academy of Sciences of the U.S.A., 67: 529-536.

DIAMOND, J. M., 1975. The island dilemma: lessons of modern biogeographic studies for the design of natural reserves. Biological Conservation, 7: 129-146. 
DIAMOND, J. M., 1976. Island biogeography and conservation: strategy and limitations. Science, 193: $1027-1029$.

DIAMOND, J. M., 1984a. "Normal" extinctions of isolated populations. In M. H. Nitecki (Ed.), Extinctions: 191-246. Chicago: University of Chicago Press.

DIAMOND, J. M., 1984b. Historic extinctions: a Rosetta Stone for understanding prehistoric extinctions. In P. S. Martin \& R. G. Klcin (Eds), Quaternary Extinctions: 824-862. Tucson: University of Arizona Press.

DRAPER, N. R. \& SMITH, H., 1981. Applied Regression Analysis. New York: John Wiley and Sons Inc.

FISCHER, A. G., 1960. Latitudinal variation in organic diversity. Evolution, 14: 64-81.

FRANKEL, O. H. \& SOULÉ, M. E., 1981. Conservation and Evolution. Cambridge: Cambridge University Press.

GILBERT, F. S., 1980. The equilibrium theory of island biogeography: fact or fiction? Journal of Biogeography, 7: 209-235.

GILPIN, M. E. \& DIAMOND, J. M., 1980. Subdivision of nature reserves and the maintenance of species diversity. Nature, 285: $567-568$.

GLEASON, H. A., 1922. On the relation between species and area. Ecology, 3: 158-162.

GLEASON, H. A., 1925. Species and area. Ecology, 6: 66-74.

GRINNELL, J. \& STORER, T. I., 1924. Animal Life in the Yosemite. Berkeley: University of California Press.

HALL, E. R., 1946. Mammals of Nevada. Berkeley: University of California Press.

HAMILTON, T. H. \& ARMSTRONG, N. E., 1965. Enviromental determination of insular variation in bird species abundance in the Gulf of Guinea. Nature, 207: 148-151.

HARMAN, W. N., 1972. Benthic substrates: their effect on fresh-water mollusca. Ecology, 53: 271-277.

HARRIS, L. D., 1984. The Fragmented Forest: Island Biogeography Theory and the Preservation of Biotic Diversity. Chicago: University of Chicago Press.

HEANEY, L. R., 1986. Biogeography of mammals in SE Asia: estimates of rates of colonization, extinction and speciation. Biological Journal of the Linnean Society, 28: 127-165.

HELLER, H. C., 1971. Altitudinal zonation of chipmunks (Eutamias): interspecific aggression. Ecology, 52: 312-319.

HELLER, H. C. \& GATES, D. M., 1971. Altitudinal zonation of chipmunks (Eutamias): energy budgets. Ecology, 52: 424-433.

HIGGS, A. J. \& USHER, M. B., 1980. Should nature reserves be large or small. Nature, 285: 568-569.

HUMPHREYS, W. F. \& KITCHENER, D. J., 1982. The effect of habitat utilization on species-area curves: implications for optimal reserve area. Joumal of Biogeography, 9: 39l-396.

IUCN COMMISSION ON NATIONAL PARKS AND PROTECTED AREAS, 1980. 1980 United Nations List of National Parks and Equivalent Reserves. Gland: IUCN.

JOHNSON, M. P. \& RAVEN, P. H., 1973. Species number and endemism: the Galápagos revisited. Science, 179: 893-895

JOHNSON, N. K., 1975. Controls of number of bird species on montane islands in the Great Basin. Evolution, 29: 545-567.

KARR, J. R., 1968. Habitat and avian diversity on strip-mined land in east-central Illinois. Condor, 70: 348-357.

KARR, J. R,, 1980. History of the habitat concept in birds and the measurement of avian habitats. In R. Nohring (Ed.), Acta XVII Congressus Internationalis Ornithologici: 991-997. Berlin: Deutsche OrnithologenGesellschaft.

KITCHENER, D. J., CHAPMAN, A., MUIR, B. G. \& PALMER, M. 1980. The conservation value for mammals of reserves in the Western Australian wheatbelt. Biological Conservation, 18: 179-207.

KUCHLER, A. W., 1966. Potential natural vegetation of the coterminous United States. Scale 1:3,168,000. American Geographical Sociely of New York, Special Publications, 36.

KUCHLER, A. W., 1975. Potential natural vegetation of the coterminous United States, 2nd edition Scale $1: 3,168,000$. American Geographical Society of New York, Special Publications, 36.

LACK, D., 1973. The numbers of species of hummingbirds in the West Indies. Evolution, 23: 193-209.

LAWLOR, T., 1983. The mammals. In T. J. Case \& M. C. Cody (Eds), Island Biogeography in the Sea of Cortez: 265-289. Berkeley: University of California Press.

LAWLOR, T. E., 1986. Comparative biogeography of mammals on islands. Biological Journal of the Linnean Society, 28: 99-125.

LYNCH, J. F. \& WHIGHAM, D. F., 1984. Effects of forest fragmentation on breeding bird communities in Maryland, U.S.A. Biological Conservation, 28: 287-324.

MACARTHUR, R. H., 1965. Patterns of species diversity. Biological Reviezes, Cambridge Philosophical Society, 40: 510-533.

MACARTHUR, R. H. \& MACARTHUR, J., 1961. On bird species diversity. Ecology, 42: 594-598.

MACARTHUR, R. M. \& WILSON, E. O., 1963. An equilibrium theory of insular zoogeography. Evolution, I7: $373-387$.

MACARTHUR, R. M. \& WILSON, E. O., 1967. The Theory of Island Biogeography. Princeton: Princeton University Press.

McGUINNESS, K. A., 1984. Equations and explanations in the study of species-area curves. Biological Reviews, Cambridge Philosophical Society, 59: 423-440. 
McNeEley, J. A. \& MILlER, K. R. (Eds), 1984. National Parks, Conservation, and Development: The Role of Protected Areas in Sustaining Society. Washington, D.C.: Smithsonian Institution Press.

MARR, J. W., 1967. Ecosystems of the east slope of the Front Range in Colorado. University of Colorado Studies, Series in Biology, 8 .

MARTIN, T. E., 1981. Species-area slopes and coefficients: a caution on their interpretation. American Naturalist, 118: 823-837.

MERRIAM, C. H., 1890. Results of a biological survey of the San Francisco Mountain region and Desert of the Little Colorado in Arizona, I. General results... with special reference to the distribution of species. North American Fauna, 3: 5-34.

MILLER, R. I. \& HARRIS, L. D, 1977. Isolation and extirpation in wildlife reserves. Biological Conservation, 12: $311-315$.

MORGAN, G. S. \& WOODS, C. A., 1986. Extinction and the zoogeography of West Indian land mammals. Biological Journal of the Linnean Society, 28: 167-203.

MORRISON, D. F., 1967. Multivariate Statistical Methods. New York: McGraw-Hill.

NETER, J. \& WASSERMAN, W., 1974. Applied Linear Statistical Models: Regression, Analysis of Variance and Experimental Designs. Homewood: Richard D. Irwin, Inc.

NEWMARK, W. D., 1986. Mammalian richness, colonization, and extinction in western North American national parks. Unpublished Ph.D. dissertation, University of Michigan, Ann Arbor, Michigan.

PATTERSON, B. D., 1980. Montane mammalian biogeography in New Mexico. Southwestern Naturalist, 25: $33-40$.

PATTERSON, B. D., 1984. Mammalian extinctions and biogeography in the southern Rocky Mountains. In M. H. Nitecki (Ed.), Extinctions: 247-293. Chicago: University of Chicago Press.

PATTERSON, B. D. \& ATMAR, W., 1986. Nested subsets and the structure of insular mammalian faunas and archipelagos. Biological Journal of the Linnean Society, 28: 65-82.

POWER, D. M., 1972. Numbers of bird species on the Galifornia Islands. Evolution, 26: 451-463.

POWER, D. M., 1976. Avifauna richness of the California Channel Islands. Condor, 78: 394-398.

PRESTON, F. W., 1960. Time and space and the variation of species. Ecology, 41: 611-627.

PRESTON, F. W., 1962. The canonical distribution of commonness and rarity. Ecology, 43: 185-215, $410-432$

REED, T. M., 1983. The role of species-area relationships in reserve choice: a British example. Biological Conservation, 25: 263-271.

REY, J. R., 1984. Experimental tests of island biogeography theory. In D. R. Strong, D. S. Simberloff, L. G. Abele \& A. B. Thistle (Eds), Ecological Communities: Conceptual Issues and the Evidence: 10I-112. Princeton: Princeton University Press.

RICKLEFS, R. E., 1979. Ecology, 2nd edition. New York: Chiron Press.

ROTENBERRY, J. T. \& WIENS, J. A., 1980. Habitat structure, patchiness, and avian communities in North American steppe vegetation: a multivariate analysis. Ecology, 61: 1228-1250.

SCHOENER, T. W., 1983. Rate of species turnover decreases from lower to higher organisms: a review of the data. Oikos, 41: 372-377.

SHAFFER, M. L. \& SAMSON, F. B., 1985. Populations size and extinction: a note on determining critical population sizes. American Naturalist, 125: $144-152$.

SIMBERLOFF, D. S., 1976. Experimental zoogeography of islands: effects of island size. Ecology, 57: $629-642$.

SIMBERLOFF, D. S., 1978. Colonization of islands by insects: immigration, extinction, and diversity. Symposia, Royal Entomological Society of London, 9: 139-153.

SIMBERLOFF, D. S. \& ABELE, L. G., 1976. Island biogeography theory and conservation practice. Science, 191: 285-286.

SIMBERLOFF, D. S. \& ABELE, L. G., 1982. Refuge design and island biogeographic theory: effects of fragmentation. American Naturalist, 120: 41-50.

SOULÉ, M. E. \& SIMBERLOFF, D. S., 1986. What do genetics and ecology tell us about the design of nature reserves? Biological Conservation, 35: 19-40.

SIMPSON, G. G., 1964. Species density of North American Recent mammals. Systematic Zoology, 13: 57-73.

SUGIHARA, G., 1981. $\mathrm{S}=\mathrm{CA}^{\mathrm{Z}}, \mathrm{Z}=1 / 4$ : A reply to Connor and McCoy. American Naturalist, 117: 790-793.

TERBORGH, J., 1971. Distribution on environmental gradients: theory and a preliminary interpretation of distributional patterns in the avifauna of the Cordillera Vilacamba, Peru. Ecology, 52: 23-40.

WALLACE, A. R., 1878. Tropical Nature and Other Essays. New York: Macmillan.

WESTERN, D. \& SSEMAKULA, J., 1981. The future of the savannah ecosystems: ecological islands or faunal enclaves? African Journal of Ecology, 19: 7-19.

WHITTAKER, R. H., 1960. Vegetation of the Siskiyou Mountains, Oregon and California. Ecological Monographs, 30: 279-338.

WHITTAKER, R. H., LEVIN, S. A. \& ROOT, R. B., 1973. Niche, habitat, and ecotope. American Naturalist, 107: $321-338$.

WILCOX, B. A. \& MURPHY, D. D., 1985. Conservation strategy: the effects of fragmentation on extinction. American Naturalist, 125: 879-887.

WILLIAMS, C. B., 1943. Area and number of species. Nature, 152: 264-267. 